\title{
ANALYSIS OF THE DISTRIBUTION INFLUENCE OF THE DENSITY OF COST-FORMING FACTORS ON RESULTS OF THE LCCA CALCULATIONS
}

\author{
M. ROGALSKA ${ }^{1}$, J. ŻELAZNA - PAWLICKA ${ }^{2}$
}

\begin{abstract}
The paper evaluates the relationship between the selection of the probability density function and the construction price, and the price of the building's life cycle, in relation to the deterministic cost estimate in terms of the minimum, mean, and maximum. The deterministic cost estimates were made based on the minimum, mean, and maximum prices: labor rates, indirect costs, profit, and the cost of equipment and materials. The net construction prices received were given different probability density distributions based on the minimum, mean, and maximum values. Twelve kinds of probability distributions were used: triangular, normal, lognormal, beta pert, gamma, beta, exponential, Laplace, Cauchy, Gumbel, Rayleigh, and uniform. The results of calculations with the event probability from 5 to $95 \%$ were subjected to the statistical comparative analysis. The dependencies between the results of calculations were determined, for which different probability density distributions of price factors were assumed. A certain price level was assigned to specific distributions in 6 groups based on the t-test. It was shown that each of the distributions analyzed is suitable for use, however, it has consequences in the form of a final result. The lowest final price is obtained using the gamma distribution, the highest is obtained by the beta distribution, beta pert, normal, and uniform.
\end{abstract}

Keywords: LCCA, statistical calculations, probability density function

\footnotetext{
${ }^{1}$ PhD., Eng., Lublin University of Technology, Faculty of Civil Engineering and Architecture, Ul. Nadbystrzycka 40 20-618 Lublin, Poland, e-mail: m.rogalska@pollub.pl

${ }^{2}$ MSc. Eng., Jan Kochanowski University in Kielce, ul. Żeromskiego 5 25-369 Kielce, Poland, e-mail: joanna.zelaznapawlicka@ujk.edu.pl
} 


\section{INTRODUCTION}

The life cycle cost analysis (LCCA) is an analytical tool for assessing the value of alternative investments. It covers the total cost of ownership, operation, and maintenance for a given building during a specific life span. The papers $[6,9,10,11,12,13]$ presents LCCA analyses that account for risk and apply fuzzy logic. The calculation requirements are defined in the ISO 15686-5 standard "Buildings and constructed assets - Service life planning - Part 5: Life-cycle costing" [7]. The standard recommends the LCCA calculations for several alternatives to the same construction activity. The analysis should be carried out in accordance with the 5.2 point of the ISO $15686-5$ for the period in which the building will maintain the function planned, in accordance with the investor's requirements. If the planned operation time of the facility is longer than 100 years, the calculation should be carried out for a period of 100 years. The shorter the period for which calculations are made, the less accurate and representative the result are, e.g., the future repairs or the recycling of building materials at the end of the building's life cycle are omitted. These costs can be a very heavy financial burden. According to the authors, the LCCA calculations for the period of durability of building's structural elements seem to be advisable. The 8.3 section of the ISO 156865 obliges to perform calculations taking into account statistical methods such as the Monte Carlo analysis. The results of the calculations should be given with a probability of $10 \%, 50 \%$, and $90 \%$. The statistical calculations are possible to perform when the probability density distributions of cost estimates prices are established. The probability density functions of prices in scientific papers are adopted in various ways. The discount rate has a normal distribution in all studies, while the distributions of other costs are different. The prices for the implementation and maintenance of pedestrian routes in [3] were determined by the triangular distribution, the prices of components, energy, and maintenance in [4] were determined by the normal and Uni distribution. In the LCCA [1], loglogistic, lognormal, and Weibull distributions were adopted - distributions were selected using the $\chi^{2}$ test according to [2]. In [5, 8], the lognormal distributions were adopted to select the correct distribution using a one-way regression analysis. In [14], to calculate the LCCA of a highway, the beta distribution of the probability density of price-forming factors was used. In the paper, 12 probability density distributions were adopted for calculations: triangular, normal, lognormal, beta pert, gamma, beta, exponential, Laplace, Cauchy, Gumbel, Rayleigh, and uniform. With regard to cost estimates for investment construction activities, it was assumed to create 3 cost estimates based on minimum, mean, and maximum values of price-forming factors. For 3 values it 
is not possible to analyze the correctness of probability density distributions with the $\chi^{2}$ test. The probabilistic approach provides more realistic information on the uncertainty of results and enables a more useful analysis of the potential benefits of design options. The probabilistic method described in this paper is based on the analysis of uncertainty and sensitivity using the Monte Carlo (MC) method. The aim of the paper is to determine what consequences cause the assumed to the calculations, the probability density distribution of the cost of building construction. The performed analysis of the results obtained may facilitate the selection of the probability density distribution in specific conditions by people, who conduct the LCCA analyzes.

\section{Calculation Method}

The proposed method of calculation consists of the following stages:

Stage 1 - preparation of three cost estimates (minimum, mean, and maximum) of the same construction project; as a result of the calculations, the minimum, mean, and maximum prices were obtained.

Stage 2 - selection of types of the probability density distributions for three cost estimates; all available distributions in the Risky Project Professional software were selected for calculation: triangular, normal, lognormal, beta pert, gamma, beta, exponential, Laplace, Cauchy, Gumbel, Rayleigh, and uniform.

Stage 3 - calculating the prices of construction works for various probability values of completing the activities in the price given by the probability distributions; probabilities $5,10,15,20,25,30$, $35,40,45,50,55,60,65,70,75,80,85,90,95 \%$ were used for calculations.

Stage 4 - graphical evaluation of the results obtained using the STATISTICA software, statistical calculations of the correlation coefficients and values of the t-test differences coefficients.

Stage 5 - analysis of the calculation results.

\section{Calculation of value of COnStRuction COST}

The calculations were carried out in a deterministic and probabilistic approach. 


\subsection{Deterministic CALCUlations}

The cost estimate was based on the superstructure project of a multi-family building. The construction project was divided into 30 processes. The Norma Pro software was used for the cost estimation. The differentiation of cost estimates consisted of the subsequent adoption of minimum, mean, and maximum cost estimate and material, equipment, and labor prices. Indirect costs were equal to 40,66 , and $80 \%$, materials purchase costs were equal to 1,6 , and $13 \%$, profit $-5,11$, and $20 \%$, respectively. The results of net calculations are presented in Table 1 .

Table 1. List of construction costs divided into processes; minimum, mean, and maximum values.

\begin{tabular}{|c|c|c|c|c|}
\hline No & Costing items & $\begin{array}{c}\text { Minimum } \\
\text { price }[\$]\end{array}$ & $\begin{array}{c}\text { Mean } \\
\text { price }[\$]\end{array}$ & $\begin{array}{c}\text { Maximum } \\
\text { price [\$] }\end{array}$ \\
\hline 1 & Demolition of cover & 16484.95 & 23268.88 & 31794.02 \\
\hline 2 & Removal of the structure & 63233.77 & 92342.89 & 131142.30 \\
\hline 3 & Demolition of masonry structures & 68069.07 & 96039.84 & 131283.39 \\
\hline 4 & Exports and disposal of rubble & 93482.72 & 101688.60 & 164064.05 \\
\hline 5 & Masonry work & 45382.11 & 95837.50 & 124246.77 \\
\hline 6 & Assembly of steel structures & 467846.87 & 567578.99 & 681453.89 \\
\hline 7 & Demolition of ceilings & 110399.43 & 154333.77 & 210177.28 \\
\hline 8 & Densely ribbed ceilings $24 \mathrm{~cm}$ thick & 329157.93 & 381181.80 & 546230.62 \\
\hline 9 & Densely ribbed ceilings $29 \mathrm{~cm}$ thick & 16927.26 & 19602.63 & 28090.42 \\
\hline 10 & Thick ribbed ceilings $26 \mathrm{~cm}$ thick & 11272.22 & 13053.81 & 18706.00 \\
\hline 11 & Preparation of reinforcement & 7975.24 & 10273.82 & 11972.47 \\
\hline 12 & Replenishment of walls and bricklaying of chimneys & 24731.31 & 52227.34 & 67709.17 \\
\hline 13 & Lightweight roof cladding & 50733.28 & 75123.44 & 112981.72 \\
\hline 14 & Roof slope formwork & 37945.08 & 47680.89 & 60903.08 \\
\hline 15 & Ventilation mat & 10907.58 & 17808.00 & 23073.73 \\
\hline 16 & Roof covering with galvanized sheet metal for rabbet & 94320.21 & 120605.46 & 153979.19 \\
\hline 17 & Roof deflectors & 5782.01 & 7993.60 & 10933.80 \\
\hline 18 & Roof gutters & 9993.84 & 13547.15 & 19232.89 \\
\hline 19 & Drain pipes & 5729.14 & 7951.78 & 10870.51 \\
\hline 20 & Roof accessories - snow fencing & 39857.76 & 48320.07 & 71465.93 \\
\hline 21 & Thermal insulation and plasterboard linings & 193356.43 & 256024.40 & 368080.28 \\
\hline 22 & Underfloor thermal insulation & 429266.00 & 461022.26 & 872148.97 \\
\hline 23 & Underfloor moisture insulation & 59536.25 & 78306.10 & 112776.53 \\
\hline 24 & Cement screeds & 170620.73 & 228189.49 & 309879.68 \\
\hline 25 & Sealing slurry insulation & 2567.49 & 14991.55 & 16395.48 \\
\hline 26 & Gres tiles cladding & 145436.72 & 226150.17 & 366780.59 \\
\hline 27 & Wall sockets & 66732.48 & 89428.57 & 123025.29 \\
\hline 28 & Ceiling linings with plasterboards & 60731.50 & 82655.90 & 111287.12 \\
\hline 29 & Painting & 6102.69 & 8769.24 & 12899.12 \\
\hline 30 & Acoustic ceilings & 56029.13 & 69935.34 & 123867.17 \\
\hline 31 & SUM & 2700611.20 & 3461933.28 & 5027451.46 \\
\hline
\end{tabular}


As a result of the calculations carried out, the deterministic net price of the superstructure was obtained: a minimum equal to 2700611.20 USD, a mean - 3461933.28 USD, and a maximum - 5027451.46 USD.

\subsection{Probabilistic Calculations}

The data obtained (minimum, mean, and maximum prices) from the deterministic calculations were used for the probabilistic calculations in the Risky Project Professional software. The different distributions of probability density were given to the same data. The following distributions were used: triangular, normal, lognormal, beta pert, gamma, beta, exponential, Laplace, Cauchy, Gumbel, Rayleigh, and uniform. Table 2 presents the results of calculations: histograms and cumulative distributions for each of the distributions analyzed. The construction costs were then calculated for different probability density distributions with respect to the percent probability of the construction completion. For the calculations, probabilities from 5 to $95 \%$ with gradation at $5 \%$ were assumed. The calculation results are summarized in Table 3.

Table 2. Histograms and cumulative distributions for the same output data using different probability density functions.

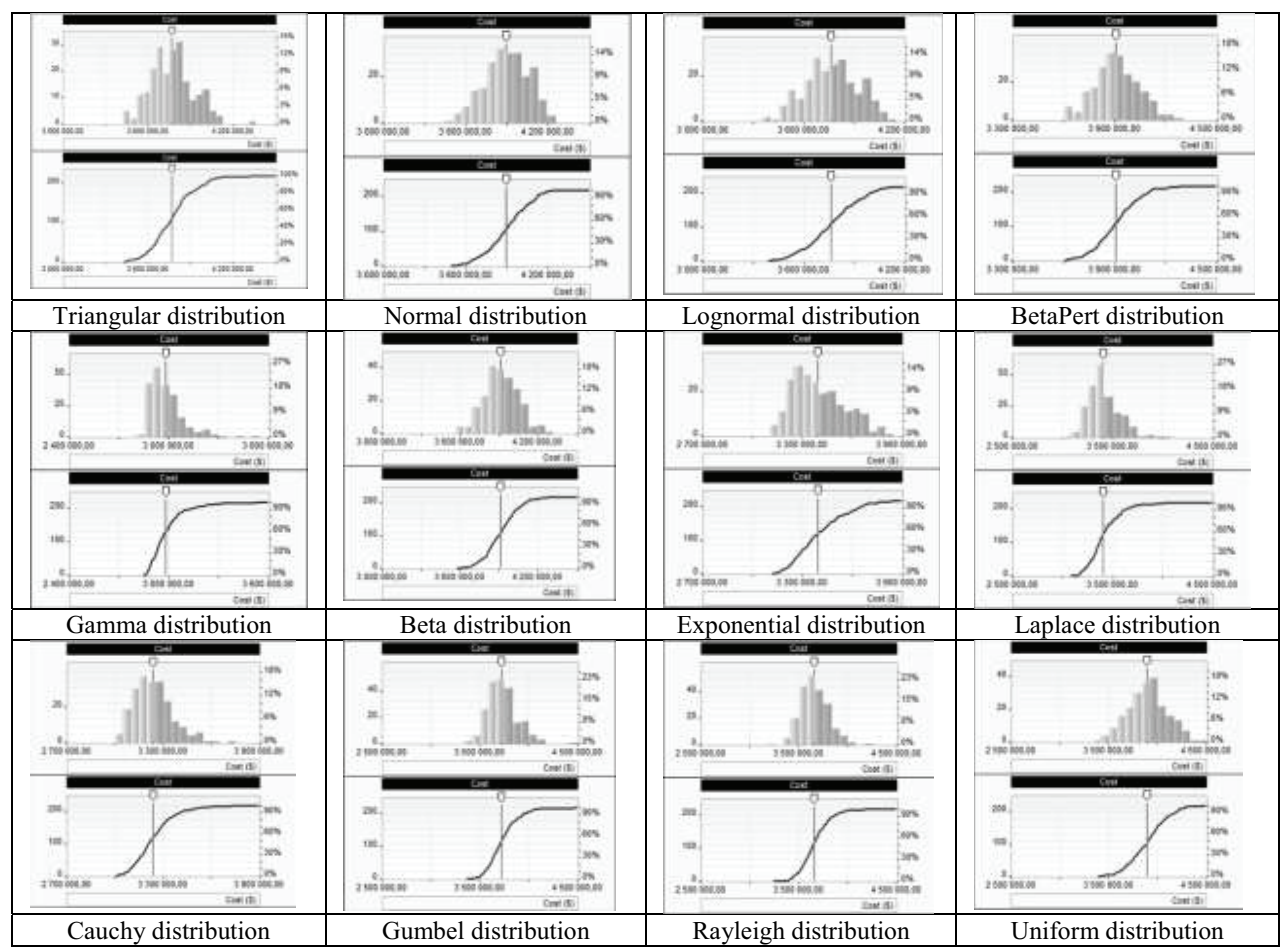


Table 3. A comparison of the percentage probability of construction prices for different probability density distributions.

\begin{tabular}{|c|c|c|c|c|c|c|}
\hline $\begin{array}{l}\text { Percentile } \\
\text { probability }\end{array}$ & GAMA & CAUCHY & EXPONENTIAL & LAPLACE & RAYLEIGH & $\begin{array}{c}\text { LOG } \\
\text { NORMAL }\end{array}$ \\
\hline$[\%]$ & [\$] & [\$] & [\$] & [\$] & {$[\$]$} & [\$] \\
\hline 5 & 2854103 & 2995929 & 3153611 & 3178187 & 3429602 & 3501468 \\
\hline 10 & 2862382 & 3020263 & 3200368 & 3224935 & 3470918 & 3538258 \\
\hline 15 & 2866682 & 3039187 & 3223556 & 3255068 & 3512341 & 3579767 \\
\hline 20 & 2879413 & 3060906 & 3240589 & 3281552 & 3536980 & 3631481 \\
\hline 25 & 2889379 & 3075058 & 3260916 & 3307997 & 3553294 & 3657562 \\
\hline 30 & 2896372 & 3091688 & 3278187 & 3324624 & 3573718 & 3673495 \\
\hline 35 & 2906217 & 3100574 & 3295262 & 3337452 & 3592524 & 3695142 \\
\hline 40 & 2912210 & 3126960 & 3326648 & 3350535 & 3617174 & 3714156 \\
\hline 45 & 2921955 & 3137993 & 3334279 & 3371656 & 3626914 & 3744673 \\
\hline 50 & 2932418 & 3151415 & 3350148 & 3380589 & 3647541 & 3760913 \\
\hline 55 & 2938646 & 3161627 & 3375316 & 3398813 & 3662790 & 3779238 \\
\hline 60 & 2957384 & 3179132 & 3402193 & 3415391 & 3683027 & 3806447 \\
\hline 65 & 2970828 & 3179132 & 3431846 & 3437371 & 3699022 & 3831024 \\
\hline 70 & 2979638 & 3195815 & 3451504 & 3459828 & 3717615 & 3843713 \\
\hline 75 & 2995796 & 3219043 & 3489767 & 3497757 & 3747909 & 3882069 \\
\hline 80 & 3007227 & 3231522 & 3529155 & 3537569 & 3774779 & 3905303 \\
\hline 85 & 3032840 & 3282320 & 3572936 & 3582935 & 3799471 & 3952575 \\
\hline 90 & 3095089 & 3323271 & 3619744 & 3604134 & 3849073 & 3981867 \\
\hline 95 & 3183623 & 3412826 & 3664145 & 3690564 & 3912647 & 4025113 \\
\hline $\begin{array}{l}\text { Percentile } \\
\text { probability }\end{array}$ & $\begin{array}{l}\text { TRIAN } \\
\text { GULAR }\end{array}$ & GUMBEL & UNIFORM & NORMAL & BETA & $\begin{array}{l}\text { BETA } \\
\text { PERT }\end{array}$ \\
\hline$[\%]$ & [\$] & [\$] & [\$] & [\$] & [\$] & [\$] \\
\hline 5 & 3534982 & 3508496 & 3569165 & 3610190 & 3698856 & 3698856 \\
\hline 10 & 3586856 & 3547258 & 3640567 & 3666565 & 3738230 & 3738230 \\
\hline 15 & 3615475 & 3580429 & 3678849 & 3715363 & 3781274 & 3781274 \\
\hline 20 & 3647045 & 3601439 & 3713807 & 3749747 & 3809459 & 3809459 \\
\hline 25 & 3665597 & 3626558 & 3754803 & 3787363 & 3822147 & 3822147 \\
\hline 30 & 3675590 & 3637286 & 3786496 & 3806482 & 3836510 & 3836510 \\
\hline 35 & 3698768 & 3651037 & 3804577 & 3833712 & 3853257 & 3853257 \\
\hline 40 & 3721005 & 3678532 & 3839147 & 3848815 & 3869499 & 3869499 \\
\hline 45 & 3749020 & 3692800 & 3884972 & 3867790 & 3888570 & 3888570 \\
\hline 50 & 3765708 & 3708152 & 3904570 & 3885609 & 3915133 & 3915133 \\
\hline
\end{tabular}




\begin{tabular}{|l|l|l|l|l|l|l|}
\hline 55 & 3781792 & 3727865 & 3928117 & 3906938 & 3928407 & 3928407 \\
\hline 60 & 3800116 & 3748543 & 3946034 & 3926531 & 3944705 & 3944705 \\
\hline 65 & 3819844 & 3770867 & 3973992 & 3947990 & 3958621 & 3958621 \\
\hline 70 & 3833286 & 3786552 & 3995871 & 3975788 & 3976382 & 3976382 \\
\hline 75 & 3853020 & 3805833 & 4028809 & 4004764 & 4002059 & 4002059 \\
\hline 80 & 3884134 & 3835825 & 4066877 & 4031533 & 4016619 & 4016619 \\
\hline 85 & 3938508 & 3880868 & 4106559 & 4078172 & 4044698 & 4044698 \\
\hline 90 & 3986283 & 3938317 & 4173023 & 4098998 & 4085114 & 4085114 \\
\hline 95 & 4026906 & 4002965 & 4228044 & 4117310 & 4123311 & 4123311 \\
\hline
\end{tabular}

\section{ANALYSIS OF THE CALCULATION RESULTS}

The results of the probabilistic calculations, summarized in Table 3, and the minimum, mean, and maximum prices from the deterministic cost estimates are presented in graphical form in Figure 1.

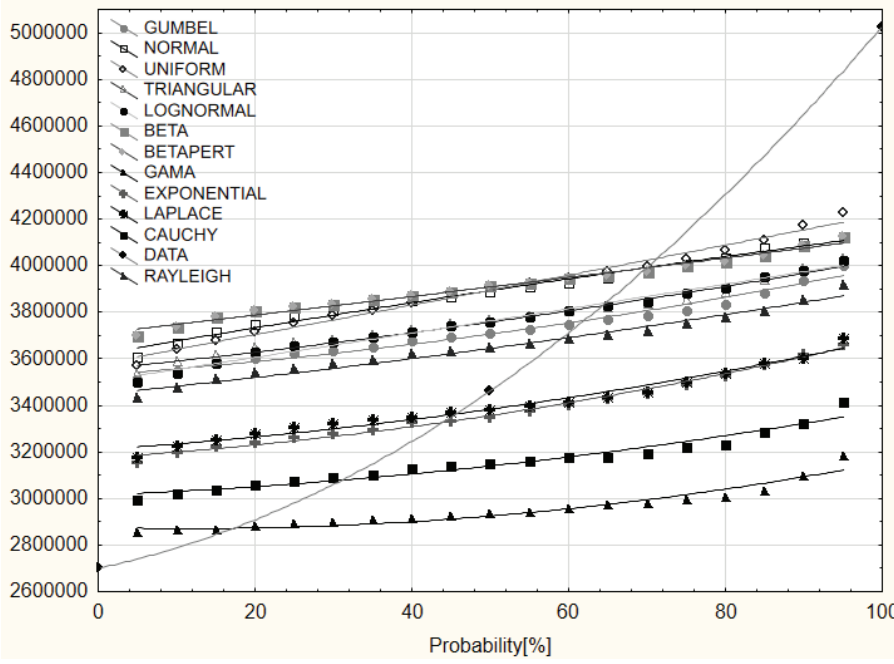

Fig. 1. Graphical presentation of probabilistic and deterministic calculations.

By analyzing the graph in Figure 1, it can be seen that all lines of the probabilistic values (probability density distributions) are strongly linearly correlated with each other. The calculated Poisson correlation coefficients reach values from 0.94 to 1.00. Tab. 4. 
Table 4. A summary of the calculations results of the Poisson correlation coefficients for all probability density functions analyzed.

\begin{tabular}{|c|c|c|c|c|c|c|c|c|c|c|c|c|}
\hline Correlations & $\begin{array}{l}\text { 乙 } \\
\stackrel{\varrho}{E} \\
\Xi \\
ٍ\end{array}$ & $\underset{\stackrel{D}{d}}{\stackrel{\square}{N}}$ & 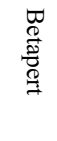 & 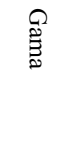 & 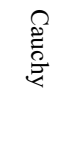 & 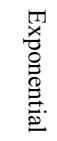 & $\frac{\vec{E}}{\overrightarrow{\tilde{D}}}$ & 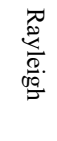 & 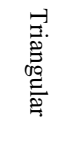 & $\begin{array}{l}5 \\
0 \\
09 \\
0 \\
0 \\
\Xi \\
0\end{array}$ & $\begin{array}{l}Q \\
\stackrel{\Xi}{\Xi} \\
\stackrel{0}{0}\end{array}$ & 灾 \\
\hline Gama & 0.92 & 0.94 & 0.94 & 1.00 & 0.99 & 0.97 & 0.97 & 0.96 & 0.96 & 0.94 & 0.97 & 0.94 \\
\hline Cauchy & .97 & 0.98 & 0.98 & 0.99 & 1.00 & 0.99 & 0.99 & 0.99 & 0.99 & 0.98 & 1.00 & 0.98 \\
\hline Expo & 0.98 & 0.99 & 0.99 & 0.97 & 0.99 & 1.00 & 1.00 & 0.99 & 0.99 & 0.99 & 1.00 & 0.99 \\
\hline Laplace & 0.98 & 0.99 & 0.99 & 0.97 & 0.99 & 1.00 & 1.00 & 1.00 & 0.99 & 0.99 & 1.00 & 0.99 \\
\hline Rayleigh & 0.99 & 1.00 & 1.00 & 0.96 & 0.99 & 0.99 & 1.00 & 1.00 & 1.00 & 1.00 & 1.00 & 1.00 \\
\hline Triangular & 0.99 & 1.00 & 1.00 & 0.96 & 0.99 & 0.99 & 0.99 & 1.00 & 1.00 & 1.00 & 1.00 & 1.00 \\
\hline Lognormal & 1.00 & 1.00 & 1.00 & 0.94 & 0.98 & 0.99 & 0.99 & 1.00 & 1.00 & 1.00 & 0.99 & 1.00 \\
\hline Gumbel & 0.98 & 0.99 & 0.99 & 0.97 & 1.00 & 1.00 & 1.00 & 1.00 & 1.00 & 0.99 & 1.00 & 0.99 \\
\hline Uniform & 1.00 & 1.00 & 1.00 & 0.94 & 0.98 & 0.99 & 0.99 & 1.00 & 1.00 & 1.00 & 0.99 & 1.00 \\
\hline Beta & 1.00 & 1.00 & 1.00 & 0.94 & 0.98 & 0.99 & 0.99 & 1.00 & 1.00 & 1.00 & 0.99 & 1.00 \\
\hline Betapert & 1.00 & 1.00 & 1.00 & 0.94 & 0.98 & 0.99 & 0.99 & 1.00 & 1.00 & 1.00 & 0.99 & 1.00 \\
\hline
\end{tabular}

This means that none of the probability density functions is an invalid function. The decision to accept a specific function will result in a selection of the solution with a specific price range: extra low, very low, low, medium, high, and very high. Giving probabilistic values causes relaxation of the deterministic extreme values. In order to determine the statistical significance of differences between groups, the t-test was made assuming a 5\% chance of making a mistake at evaluation $(p=$ 0.05 ) and the number of freedom equal to 9 . The number of degrees of freedom is the number of independent observation results minus the number of relations that combine these results with each other. In the case analyzed, the number of relations combining the results is 3 and they are the minimum, mean, and maximum prices from the deterministic cost estimates. The number of independent results equals 12 - the number of the probability density functions. The critical value of the t-test for the probability of 0.05 and 9 degrees of freedom is equal to 0.7027 . If the absolute value of the t-test will have a value above 0.7027 , it will mean that the hypothesis of equality of variables can not be accepted - the variables will be different. Table 5 presents the results of the significance test of the t-test. 
Table 5. The values of the $t$ coefficient of the $t$-test for the probability density functions.

\begin{tabular}{|c|c|c|c|c|c|c|c|c|c|c|c|c|}
\hline Correlations & 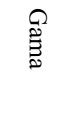 & $\begin{array}{l}\stackrel{2}{E} \\
\stackrel{0}{Z}\end{array}$ & 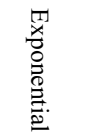 & 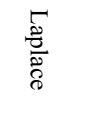 & 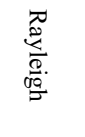 & 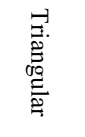 & 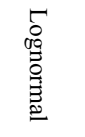 & $\begin{array}{l}\stackrel{Q}{\Xi} \\
\underset{\Xi}{\Xi} \\
\Xi\end{array}$ & 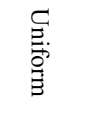 & 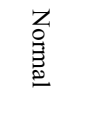 & $\begin{array}{l}\stackrel{\vec{W}}{\vec{\omega}} \\
\stackrel{\omega}{\omega}\end{array}$ & 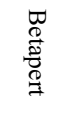 \\
\hline Gama & 0.00 & -6.58 & -11.04 & -12.29 & -19.88 & -22.41 & -20.71 & -21.44 & -20.54 & -24.31 & -24.31 & -29.11 \\
\hline Cauchy & 6.58 & 0.00 & -5.36 & -6.20 & -12.96 & -15.54 & -14.47 & -14.54 & -15.30 & -17.71 & -17.71 & -20.86 \\
\hline Exponential & 11.04 & 5.36 & 0.00 & -0.50 & -6.15 & -8.55 & -8.05 & -7.62 & -9.67 & -10.78 & -10.78 & -12.43 \\
\hline Laplace & 12.29 & 6.20 & 0.50 & 0.00 & -5.87 & -8.36 & -7.84 & -7.40 & -9.51 & -10.67 & -10.67 & -12.43 \\
\hline Rayleigh & 19.88 & 12.96 & 6.15 & 5.87 & 0.00 & -2.69 & -2.45 & -1.65 & -4.76 & -5.28 & -5.28 & -6.48 \\
\hline Triangular & 22.41 & 15.54 & 8.55 & 8.36 & 2.69 & 0.00 & 0.09 & 1.04 & -2.48 & -2.64 & -2.64 & -3.51 \\
\hline Lognormal & 20.71 & 14.47 & 8.05 & 7.84 & 2.45 & -0.09 & 0.00 & 0.90 & -2.46 & -2.61 & -2.61 & -3.40 \\
\hline Gumbel & 21.44 & 14.54 & 7.62 & 7.40 & 1.65 & -1.04 & -0.90 & 0.00 & -3.37 & -3.67 & -3.67 & -4.66 \\
\hline Uniform & 20.54 & 15.30 & 9.67 & 9.51 & 4.76 & 2.48 & 2.46 & 3.37 & 0.00 & 0.16 & 0.16 & -0.29 \\
\hline Normal & 24.31 & 17.71 & 10.78 & 10.67 & 5.28 & 2.64 & 2.61 & 3.67 & -0.16 & 0.00 & 0.00 & -0.54 \\
\hline Beta & 29.11 & 20.86 & 12.43 & 12.43 & 6.48 & 3.51 & 3.40 & 4.66 & 0.29 & 0.54 & 0.54 & 0.00 \\
\hline Betapert & 29.11 & 20.86 & 12.43 & 12.43 & 6.48 & 3.51 & 3.40 & 4.66 & 0.29 & 0.54 & 0.54 & $\mathbf{0 . 0 0}$ \\
\hline
\end{tabular}

The calculations show that the probability density functions analyzed form 6 groups. No statistically significant differences in the following groups can be specified:

Group 1 - extramely low price - the gamma function,

Group 2 - low price - the Cauchy function,

Group 3 - medium price - the exponential and Laplace functions,

Group 4 - medium high price - the Rayleigh function,

Group 5 - high price - the triangular, lognormal, and Gumbel functions,

Group 6 - very high price - uniform, normal, beta, and beta pert functions.

The sequential chart of the raw data in Figure 2 illustrates the separation of 6 groups of the probability density functions (based on the t-test). 


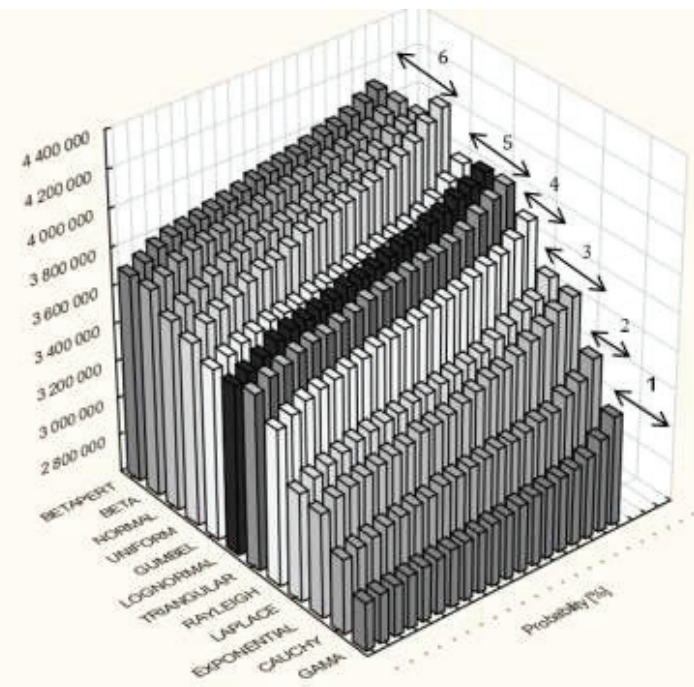

Fig. 2. The sequential chart of the raw data

\section{SUMMARY AND CONCLUSIONS}

When carrying out a cost analysis in accordance with the ISO 15686-5 standard "Buildings and constructed assets - Service life planning- Part 5: Life-cycle costing”, a specific probability density function should be adopted for the calculations. The paper shows the relationship between the selection of the probability density function and the analyst's intention as to the proposed construction price and the price of the building's life cycle, in relation to the deterministic cost estimate in terms of the minimum, mean, and maximum. Specific price levels have been assigned to specific distributions in 6 groups. It was shown that each of the distributions analyzed is acceptable, but it has consequences in the form of a final result. The lowest final price is obtained using the gamma distribution, the highest - the beta, beta pert, normal, and uniform distributions. The results were confirmed by the t-test. 


\section{REFERENCES}

1. A. Abdelaty, D.J. Hyungseok, B. Dannen, F. Todey, “Enhancing life cycle cost analysis with a novel cost classification framework for pavement rehabilitation projects”. Construction Management \& Economics. 2016, Vol. 34 Issue 10, p724-736.

2. D. S. Moore, "Tests of Chi-Squared Type Goodness of Fit Techniques," 1986.

3. D. Wu, H. Liu, C. Yuan, "A risk-based optimisation for pavement preventative maintenance with probabilistic LCCA: a Chinese case”. International Journal of Pavement Engineering, 2 January 2017, 18(1):11-25

4. E. Di Giuseppe, A. Massi, M. D’Orazio, "Probabilistic Life Cycle Cost analysis of building energy efficiency measures: selection and characterization of the stochastic inputs through a case study". International HighPerformance Built Environment Conference - A Sustainable Built Environment Conference 2016 Series (SBE16), iHBE 2016, Procedia Engineering. 2017 180:491-501

5. E. Fregonara, D. G. Ferrando, "How to Model Uncertain Service Life and Durability of Components in Life Cycle Cost Analysis Applications? The Stochastic Approach to the Factor Method". Sustainability 2018, $10(10), 3642$

6. Ilg.P.,Scope,C.,Muench, s.and Guenther, E.2017. Uncertainty in life cycle costing for long-range infrastructure. Part I: leveling the playing field to address uncertainties. International Journal of life cycle Assessment. 22, 2, 277-292.

7. ISO 15686-5 Buildings and constructed assets- Service life planning- Part 5: Life-cycle costing

8. O.Swei, J. Gregory, R. Kirchain, "Probabilistic Characterization of Uncertain Inputs in the Life-Cycle Cost Analysis of Pavements Transportation Research Record". Journal of the Transportation Research Board, No. 2366, Transportation Research Board of the National Academies, Washington, D.C., 2013, pp. 71-77.

9. Oduyemi, O., Okorch, M. and Fajana, O.S. 2016. Risk assestment mathods for life cycle costing in buildings., Sustainable buildings. 1 .

10. Plebankiewicz, E., Zima, K. and Wieczorek, D. 2016. Life cycle cost modelling of buildings with consideration of the risk. Archives of Civil Engineering. 62, 2, 149-166.

11. Plebankiewicz, E., Zima, K. and Wieczorek, D. 2016. Quantification of the risk addition in life cycle cost of a building object. Czasopismo Techniczne. 5, 35-45.

12. Scope,C., Ilg.P., Muench, s.and Guenther, E.2016. Uncertainty in life cycle costing for long-range infrastructure. Part II: guidance and suitability of applied methods to address uncertainty. International Journal of life cycle Assessment. 21, 8, 1170-1184.

13. Wieczorek, D., Plebankiewicz, E. and Zima, K. 2019. Model Estimation of the Whole Life Cost of a Building with respect to Risk Factors. Technological and Economic Development of Economy. 25, 1, 20-38.

14. Z. Li, S. Madanu," Highway Project Level Life-Cycle Benefit/Cost Analysis under Certainty, Risk, and Uncertainty: Methodology with Case Study”. Journal of the Transportation Engineering (C ASCE / August 2009 ,

\section{LIST OF FIGURES AND TABLES:}

Fig. 1. Graphical presentation of probabilistic and deterministic calculations.

Fig. 2. The sequence chart of the raw data

Rys. 1. Graficzne odwzorowanie obliczeń probabilistycznych i deterministycznych

Rys. 2. Wykres sekwencyjny danych surowych

Tab. 1. List of construction costs divided into processes; minimum, average, and maximum values

Tab. 2. Histograms and cumulative distributions for the same output data using different probability density functions

Tab. 3. A comparison of the percentage probability of construction prices for different probability density distributions

Tab. 4. A summary of the calculations results of the Poisson correlation coefficients for all probability density functions analyzed 
Tab. 5. The values of the $t$ coefficient of the t-test for the probability density functions.

Tab. 1. Zestawienie kosztów budowy z podziałem na procesy; wartości minimalne, średnie i maksymalne Tab. 2. Histogramy i dystrybuanty funkcji gęstości prawdopodobieństwa.

Tab. 3. Zestawienie procentowego prawdopodobieństwa cen budowy dla różnych rozkładów gęstości prawdopodobieństwa

Tab. 4. Zestawienie wyników obliczeń wartości współczynników korelacji Poissona

Tab. 5.Wartości współczynnika t testu t- Studenta dla funkcji gęstości prawdopodobieństwa

\section{ANALIZA WPLYWU ROZKŁADÓW GESTOŚCI PRAWDOPODOBIEŃSTWA CZYNNIKÓW CENOTWÓRCZYCH NA WYNIKI OBLICZEŃ LCCA}

Slowa kluczowe: LCCA, obliczenia statystyczne, funkcja gęstości prawdopodobieństwa

\section{STRESZCZENIE}

W artykule wykazano związek pomiędzy wyborem funkcji gęstości prawdopodobieństwa a ceną budowy i ceną cyklu życia budynku, w odniesieniu do posiadanego deterministycznego kosztorysu w ujęciu minimalnym, średnim i maksymalnym. Wykonano kosztorysy deterministyczne realizacji inwestycji bazując na cenach minimalnych, średnich i maksymalnych : stawki robocizny, kosztów pośrednich, zysku oraz ceny pracy sprzętu i materiałów. Otrzymanym cenom netto budowy nadawano różne rozkłady gęstości prawdopodobieństwa bazując na wartości minimalnej, średniej i maksymalnej. Wykorzystano 12 rodzajów rozkładów prawdopodobieństwa: trójkątny, normalny, lognormalny, beta pert, gamma, beta, exponential, Laplaca, Cauchy, Gumbel, Rayleigh, uniform. Wyniki obliczeń przy prawdopodobieństwach zdarzenia od 5 do $95 \%$ poddano statystycznej analizie porównawczej. Określono zależności pomiędzy wynikami obliczeń dla których przyjęto rożne rozkłady gęstości prawdopodobieństwa czynników cenotwórczych. Przypisano określonym rozkładom poziom wysokości cen w 6 grupach na podstawie przeprowadzonego testu t-Studenta. Wykazano, że każdy z analizowanych rozkładów nadaje się do stosowania, powoduje to jednak konsekwencje w postaci wyniku końcowego. Najniższą cenę końcową uzyskamy stosując rozkład Gama, najwyższą rozkład Beta, Betapert, Normalny i Uniform. 